\title{
Evaluation of chemical composition of candy developed from tigernut (Cyperus esculentus) milk
}

\author{
${ }^{1 *}$ Okudu H.O and Ogubuike L.A
}

\author{
${ }^{1,2}$ Department of Human Nutrition and Dietetics Michael Okpara University of Agriculture Umudike, Abia State \\ *Corresponding Author E-mail: helenokudu@yahoo.com, Tel: +2340869189948.
}

\begin{abstract}
Tigernut (Cyperus esculentus) was bought from Amawusa Market in Umuahia town, Abia State. The seeds were purchased from five randomly selected vendors in the market and pooled to obtain the sample for analysis. Undamaged seeds were selected for the production of the candy. Tiger nut seeds $(800 \mathrm{~g})$ were soaked for 8 hours in potable water, and then ground in a ratio of 1 liter of water to each $300 \mathrm{gram}$ of tiger nuts. The mixture was left to macerate for 10 minutes. The mixture was pressed and filtered using a muslin cloth. Standard method was used to prepare the candy. The proximate and vitamin content of the samples were also determined using standard AOAC methods. Mineral elements were determined using wet-acid digestion method for multiple nutrients determination. All tests were carried out in duplicates and the data generated were analysed using standard methods. The proximate result shows that tigernut candy contains crude protein $(2.78 \%)$, crude fat $(24.84 \%)$, and crude fiber $(0.04 \%)$ respectively. The calcium, potassium, phosphorus and iron contents were found to be $64.54,132.82,50.54$ and $4.49 \mathrm{mg} / 100 \mathrm{~g}$. The $\beta$ - carotene was $83.82 \mu \mathrm{g} / 100 \mathrm{~g}$, while the vitamins $E, B_{2}$ and $B_{3}$ were found to be $2.08,0.09$ and $0.09 \mathrm{mg} / 100 \mathrm{~g}$. The saponin and oxalate each was $0.24 \%$. The study showed that candy produced from tigernut milk is a relatively good source of protein, fat, calcium, potassium, and iron. Fiber found on tiger nut candy is also an added value.
\end{abstract}

Keywords: Cyperus esculentus, candy, plant milk.

\section{INTRODUCTION}

Regardless of the many successes of agriculture during the last several decades, it is clear that current methods and levels of food production and consumption particularly in the developing countries are not sustainable (FAO, 2013). In Nigeria, aside inadequate food production, uneven distribution of food, poor food preservation techniques, improper preparation of foods, food restrictions and taboos (Igbedioh, 1993), and high cost of animal products is the cause of malnutrition in individuals; there is therefore need the use plant source as alternative. Tigernut (Cyperus esculentus) is an underutilized tuber that belongs to the family Cyperaceae. It is widely distributed in the temperature zones within South Europe as its probable origin, but has become naturalized in Ghana, Nigeria and Sierra Leone (Anon, 1992; Bamishaiye and Bamishaiye, 2011). Tigernut is commonly known as earth almond, chufa and chew-fa and Zulu nuts. It is known in Nigeria as Aya in Hausa, Ofio in Yoruba and, Akihausa in Igbo where three varieties (black, brown and yellow) are found. Among these, only two varieties, yellow and brown are readily available in the market. Traditionally, in Nigeria, tigernut tubers are eaten unprepared, roasted with sugar, soaked in water or be processed into starch (Watt and BreyerBrandwijk, 1962; Bamishaiye and Bamishaiye, 2011) and flour. Processing tiger nut into candies could play important role in the conservation and better utilization of tigrnut; it will also ensures fair returns to growers to improve their economic condition which in turn help to mitigate the problem of under-employment during offseasons in the agricultural sectors (Vidhya and Narain, 2010). This study was designed to develop candy from tigernut milk and to evaluate its nutrients and antinutrient composition.

\section{MATERIALS AND METHODS}

\section{Source of materials/ selection of tiger nut}

Tigernut (yellow variety) was bought from Amawua 
market in Umuahia town, Abia State. The seeds were purchased from five randomly selected vendors in the market and pooled to obtain the sample for analysis. Undamaged seeds were selected for the production of the candy. Sorting was done by hand.

\section{Extraction of tigernut milk}

The method as described by Obasi and Ugwu (2015) with some modification was adopted for the extraction of the milk. Tiger nut seeds $(800 \mathrm{~g})$ were soaked for 8 hours in potable water, and then ground in a ratio of 1 liter of water to each $300 \mathrm{gram}$ of tiger nuts. The mixture was left to macerate for 10 minutes. The mixture was pressed and filtered using a muslin cloth.

\section{Milk Candy Production}

The method described by Obasi and Ugwu (2015) was adopted. One hundred (100)g of sugar, $30 \mathrm{~g}$ of glucose syrup, and $8 \mathrm{~g}$ of lime juice were combined in a heavy sauce pan over medium heat $\left(45^{\circ} \mathrm{C}\right)$ and stirred until the sugar dissolved. A thermometer was inserted into the mixture as it was brought to boiling without stirring until the temperature of the mixture reaches $120^{\circ} \mathrm{C}$ and this lasted for one hour. The mixture was allowed to cool to about $45^{\circ} \mathrm{C}$ before pouring into suitable molds to form. The resulting candies were removed from the molds after 30 minutes, cut with a very sharp knife and was left to cool for 24 hours. The candies were wrapped in an aluminum foil and stored in an airtight container at room temperature prior to analysis.

\section{Chemical analyses}

The proximate compositions of the sample were determined using standard A.O.A.C. (2006) methods. Moisture content of the jam was determined gravimetrically. The crude protein content was determined by micro-Kjeldahl method, using 6.25 as the nitrogen conversion factor. The crude fat content was determined by Soxhlet extraction method using petroleum ether. The ash content was determined by incinerating the samples at $600^{\circ} \mathrm{C}$ in a muffle furnace.

Mineral elements were determined using wet-acid digestion method for multiple nutrients determination as described by the method of A.O.A.C (2006). About $0.2 \mathrm{~g}$ of the processed sample material was weighed into a $150 \mathrm{ml}$ Pyrex conical flask. Five (5.0) $\mathrm{ml}$ of the extracting mixture $\left(\mathrm{H}_{2} \mathrm{SO}_{4}\right.$ - Sodium Salicylic acid) was added to the sample. The mixture was allowed to stand for 16 hours. The mixture was then placed on a hot plate set at $300 \mathrm{C}$ and allowed to heat for about 2hours. Five (5.0) $\mathrm{ml}$ of concentrated perchloric acid was introduced to the sample and heated vigorously until the sample was digested to a clear solution. Twenty (20) milliliters of distilled $\mathrm{H}_{2} \mathrm{O}$ was added and heated to mix thoroughly for about a minute. The digest was allowed to cool and was transferred into a $50 \mathrm{ml}$ volumetric flask and made up to the mark with distilled water. The digest was used for the determinations of calcium $(\mathrm{Ca})$ and magnesium $(\mathrm{Mg})$ by the ethylamine ditetra acetic acid (EDTA) versanate complexiometric titration method. Potassium $(\mathrm{K})$ and sodium $(\mathrm{Na})$ were evaluated by flame photometry method and phosphorus $(P)$ by the vanadomolybdate method using the spectrophotometer. The trace metal (iron) was determined using the atomic absorption spectrophotometer 969 instrument. The appropriate cathode lamp was fixed for each element. The sample was introduced to the atomizer and the value concentration of the element printed out as $\mathrm{mgX/liter}$. The $\beta$ - carotene, riboflavin, niacin and thiamin of the products were determined spectrophotometrically as described by AOAC (2006). While ascorbic acid was determined as described by AOAC (2006) using titration method. Gravimetric method (Harborne, 1973) was used to determine alkaloids. Saponin was determined by gravimetric oven drying method as described by the method of A.O.A.C (2006). Tannin content of the sample was determined spectrophometrically as described by Kirk and Sawyer (1991).

Carbohydrate was obtained by difference, while energy was calculated using the Atwater Conversion factors in $\mathrm{KJ}(17 \mathrm{KJ}, 17 \mathrm{KJ}$, and $37 \mathrm{KJ}$, for protein, carbohydrate and lipid respectively.

\section{RESULT AND DISCUSSION}

\section{Energy and proximate composition of tigernut (Cyperus esculentus) candy}

The energy and proximate composition of tigernut candy is presented on Table 1 . The moisture content of tigernut candy $(45.49 \%)$ in this study was higher than those reported for tigernut candy and melon candy (Obasi and Ugwu, 2014) in a similar study. The high moisture found in this study could be due to the modification done to the method. The protein content of the product $(2.78 \%)$ was lower $3.86 \%$ reported in a similar study. Though the protein found in this study was low, the consumption of tigernut candy can contribute to cumulative intake of protein of individuals that consumes it. The crude fat value of tigernut candy was $28.84 \%$. The high fat seen in the product could be as a result of the high fat originally found in raw tigernut (Bamishaiye and Bamishaiye, 2011). Tigernut oil is reported to be comparable to that of olive oil in terms of their health benefit properties, also tigernut oil have high oleic acid and low polyunsaturated fatty acid (Okladnikov et al., 1977; Ezebor et al., 2005). The crude fiber value of tigernut oil was $0.04 \%$. There 
Table 1. Energy and Proximate Composition of tigernut ((Cyperus esculentus) candy

\begin{tabular}{ll}
\hline Nutrient & Quantity \\
\hline Moisture (\%) & $45.69 \pm 0.15$ \\
Crude protein (\%) & $2.78 \pm 0.02$ \\
Crude fat (\%) & $28.84 \pm 008$ \\
Crude fiber (\%) & $0.04 \pm 0.01$ \\
Ash (\%) & $1.64 \pm 0.0$ \\
Carbohydrate (\%) & 21.21 \\
Energy (KJ/Kcal) & $1326 / 355$ \\
\hline
\end{tabular}

Table 2. Mineral Composition of tigernut (Cyperus esculentus) candy

\begin{tabular}{ll}
\hline Nutrient & Quantity \\
\hline Calcium $(\mathrm{mg} / 100 \mathrm{~g})$ & $64.54 \pm 0.08$ \\
Potassium $(\mathrm{mg} / 100 \mathrm{~g})$ & $132.82 \pm 0.00$ \\
Magnesium $(\mathrm{mg} / 100 \mathrm{~g})$ & $15.77 \pm 0.04$ \\
Sodium $(\mathrm{mg} / 100 \mathrm{~g})$ & $62.68 \pm 0.72$ \\
Iron $(\mathrm{mg} / 100 \mathrm{~g})$ & $4.49 \pm 0.01$ \\
Phosphorus $(\mathrm{mg} / 100 \mathrm{~g})$ & $50.54 \pm 0.07$ \\
$\mathrm{Ca} / \mathrm{P}$ & 1.27 \\
$\mathrm{~K} / \mathrm{Na}$ & 2.10 \\
\hline
\end{tabular}

was no similar work to compare the value of crude fiber with. The role of crude fiber in the prevention of certain cancer has been documented (Bamishaiye and Bamishaiye, 2011). This implies that apart from being a source of nutrient, consumption of tigernut candy can be of health benefit to individuals. The carbohydrate and energy values of the products were $21.12 \%$ and $1326 \mathrm{kj}$ respectively.

\section{Mineral composition of tigernut (Cyperus esculentus) candy}

The mineral composition of tigernut candy is on Table 2 . The result shows that tigernut candy is a relatively good source of mineral. Calcium and phosphorus values $(64.54 \mathrm{mg} / 100 \mathrm{~g} 132,82 \mathrm{mg} / 100 \mathrm{~g}$ respectively) found in this study were lower calcium phosphorus values reported in a similar study. The difference in their calcium and phosphorus values can be attributed to varietal difference. The recommended daily intake of calcium and phosphorus for children 4-8years are $800 \mathrm{mg} / \mathrm{d}$ and $700 \mathrm{mg} / \mathrm{d}$ respectively. This implies that $100 \mathrm{~g}$ of tigernut candy can supply that age group with $8 \%$ and $18 \%$ respectively of their calcium and phosphorus daily need. Also, the magnesium and sodium values $(15.77 \mathrm{mg} / 100 \mathrm{~g}$ and $62.68 \mathrm{mg} / 100 \mathrm{~g}$ respectively) were lower than $47.50 \mathrm{mg} / 100 \mathrm{~g}$ and $180.50 \mathrm{mg} / 100 \mathrm{~g}$ reported for magnesium and sodium in a similar study. The iron value of the product was $4.47 \mathrm{mg} / 100 \mathrm{~g}$. Of interest are the relatively high calcium and potassium contents of the product. These two macronutrients play very vital roles in the body. Calcium plays important role in formation and maintenance of bone in the body while potassium has been shown to be essential for the normal functioning of nerves and muscle and in maintain the acid-base balance of the body (Tolonen, 1990). The sodium content of tigernut candy was relatively high, but according to Dietary Guideline Advisory Committee (2011), the benefits of dietary potassium on blood pressure are strongest in salt sensitive individuals as a result potassium and sodium should be consider together. Also the calcium: phosphorus ratio was found to be greater than one, indicating that these minerals are in the correct proportion in the product.

\section{Vitamin composition of tigernut (Cyperus esculentus) candy}

The vitamin composition of tigernut candy is shown on Table 3., the carotene value of the product was $83.82 \mathrm{mcg} / 100 \mathrm{~g}$.there was no similar work to compare the carotene value of tigernut candy with but when compare with other plant foods, the carotene content of tigernut candy $(83.82 \mathrm{mcg} / 100 \mathrm{~g})$ was higher than that of raw sesame seed, raw avocado pulp, but lower than that of raw ripe tomato (Stadimayr et al., 2011). Carotene acts as a good antioxidant and also as a precursor of vitamin $A$ (Rao and Rao, 2007). The vitamin $C, B_{2}$, and $B_{3}$ $(0.36 \mathrm{mg} / 100 \mathrm{~g}, \quad 0.09 \mathrm{mg} / 100 \mathrm{~g}, \quad$ and $\quad 0.09 \mathrm{mg} / 100 \mathrm{~g}$ respectively) were relatively low. Consumption of tigernut candy in combination with other foods will however, add to cumulative intake of these nutrients. The vitamin $E$ 
030 Afr. J. Food Sci. Technol.

Table 3. Vitamin composition of tigernut (Cyperus esculentus) candy

\begin{tabular}{ll}
\hline Nutrient & Quantity \\
\hline$\beta$-Carotene $(\mathrm{mcg} / 100 \mathrm{~g})$ & $83.82 \pm 0.02$ \\
Vitamin C $(\mathrm{mg} / 100 \mathrm{~g})$ & $0.36 \pm 0.36$ \\
Vitamin E $(\mathrm{mg} / 100 \mathrm{~g})$ & $2.08 \pm 0.00$ \\
Vitamin B2 $(\mathrm{mg} / 100 \mathrm{~g})$ & $0.09 \pm 0.00$ \\
Vitamin B3 $(\mathrm{mg} / 100 \mathrm{~g})$ & $0.09 \pm 0.00$ \\
\hline
\end{tabular}

Table 4.Phytochemical Composition of tigernut (Cyperus esculentus)candy

\begin{tabular}{ll}
\hline Nutrient & Quantity \\
\hline Saponin $(\mathrm{mg} / 100 \mathrm{~g})$ & $24.2 \pm 0.01$ \\
Alkaloid $(\mathrm{mg} / 100 \mathrm{~g})$ & $1.00 \pm 0.00$ \\
Tannin $(\mathrm{mg} / 100 \mathrm{~g})$ & 0.00 \\
Phytate $(\mathrm{mg} / 100 \mathrm{~g})$ & 0.00 \\
Oxalate $(\mathrm{mg} / 100 \mathrm{~g})$ & $24.0 \pm 0.01$ \\
\hline
\end{tabular}

content of the product was $2.08 \mathrm{mg} / 100 \mathrm{~g}$. Vitamin $E$ is known for its antioxidant activity.

\section{Antinutrient composition of tigernut (Cyperus esculentus) candy}

The result of antinutrient composition of tigernut candy is provided on Table 4. The result showed that tigernut candy contained saponin, alkaloid and oxalate $(24.0 \mathrm{mg} / 100 \mathrm{~g}, \quad 1.0 \mathrm{mg} / 100 \mathrm{~g}, \quad$ and $\quad 24.0 \mathrm{mg} / 100 \mathrm{~g}$ respectively). Tannin and phytate were not detected. It was noted that the values of saponin, alkaloid and oxalate in tigernut candy were below $1 \%$. This implies that the product is very safe for consumption.

\section{CONCLUSION}

The study showed that candy produced from tigernut milk is a relatively good source of protein, fat, calcium, potassium, and iron. Fiber found on tiger nut candy is also an added value.

\section{REFERENCES}

Anon A(1992). Cyperules. In: The new Encyclopedia Britannica, Macropaedia Chicago. 3: 185.

Association of Official Analytical Chemist AOAC. (2006). Official Methods of Analysis.

Association of Official Analytical Chemistry, Washington D.C.

Bamishaiye El, Bamishaiye $\mathrm{OM}(2011)$. Tiger nut: As a plant, its derivatives and benefits.

African Food Agric. Nutr. Dev. 11(5): 5157-5170.

Black RE, Allen LH, Bhutta ZA, Caulfield LE, de Onis M, Ezzati M, Rivera J (2008). Maternal and child undernutrition: Global and regional exposures and health consequences. The Lancet. 371: 243-260.

Dietary Guidelines Advisory Committee (DGAC) (2011). Report of the Dietary

Guidelines. Advisory committee on the Dietary Guidelines for Americans,

2010.Washington, .DC: U.S Deparment of Agriculture, Agricultural Research

Service.

Ezebor F, Igwe CC, Owolabi FAT, Okoh SO(2005). Comparison of the physico-chemical characteristics, oxidative and hydrolytic stabilities of oil and fat of cyperus esculentus $L$. and butyrospermum parkii (shea nut) from Middle-Belt States of Nigeria.Nigerian Food J. 23: 33-39.

FAO. (2013) Greening the Economy with Agriculture - Utilization. In: Greening the

Economy with Agriculture. Swiss Federation and FAO, Rome.

Harboune JB(1973). phytochemical methods: a guide to modern technique of plants

analysis. Chapman and hall: London. pp 60-64.

Igbedioh SO(1993). Undernutrition in Nigeria dimention, causes and remedies for alberiation in a changing socio-economic environment. Nutr. Health. 9:1-14.

Kirk RS, Sawyer R(1991). Pearson' composition and analysis of foods. $9^{\text {th }}$ Edition, Longman Scientific and Technical. United Kingdom.

Obasi NE, Ugwu VC(2015). Quality Characteristics of Candies Produced from Tiger Nuts Tubers (Cyperus esculentus) and Melon Seeds (Colocynthis citrullus. L) Milk Blend. Global J. Sci. Frontier Res. 15 (2): 10-20

Okladnikov I, Vorkel L, Trubachev I, Vlasova N, Kalacheva G(1977) Inclusion of chufa in the human diet as a source of polyunsaturated fatty acids. Voprosy Pitaniia 3:45-48.

Rao AV, Rao LG(2007). Carotenoids and human health. Pharmacol. Res: 5: 207-216.

Stadimayr B, Charrondiere UR, nujiugha VN, Romric GB, Etel G, Fagbohoun Samb B, Addy P, Barikmo IB, Ouattara F, Oshaug A Akinyele I, Annor GA, Bomfeh K, Ene-Obong H, Smith IF, Thiam I and Burlingame $\mathrm{B}(2012)$. West Africa Food Composition Table/ Table de composition des aliments d'Afrique de IOuest.Food Agriculture Oganization of the United Nations. Rome.

Tolonen, M. (1990). Vitamin and minerals in Health and Nutrition Ellis Horwood Ltd. England. Pp 45-68.

Vidhya R, Narain A (2010). Development of preserved products 
(jam and fruit bar) from under exploited wood apple "Limonia acidissima" fruits. African J. Fd. Sci.Tech. Pp 051-057.

Watt K, Breyer-Brandwijk B(1992). Entry of Cyperus esculentus in Africa In: The useful plants of west tropical Africa Linn 365:373.
Wardlaw GM, Hampl JS(2007). Perspectives in nutrition. $7^{\text {th }}$ ed.New York McGraw Hill. Pp 54-244. 